\title{
The economic feasibility of cultivating intensive orchards
}

\author{
Bakhodir Sultanov ${ }^{1}$, Napisa Abdurazakova ${ }^{2}$, Odiljon Shermatov ${ }^{3}$, Oybek Fayziev ${ }^{4}$, Azamat \\ Jumanov $^{2}$, and Nilufar Dekhkanova ${ }^{4 *}$ \\ ${ }^{1}$ Tashkent State University of Economics, 49 Uzbekistan street, 100003, Tashkent, Uzbekistan \\ ${ }^{2}$ Tashkent institute of irrigation and agricultural mechanization engineers, 39, Kari Niyazov street, \\ 100000, Tashkent, Uzbekistan \\ ${ }^{3}$ Andijan Institute of Agriculture and Agro Technologies, 1 Oliygokh Street, Kuygan-Yor town, \\ 170600, Andijan region, Uzbekistan \\ ${ }^{4}$ Tashkent State Agrarian University, 2 Universitetskaya, 700140 Tashkent, Uzbekistan
}

\begin{abstract}
Horticulture is an important part of agriculture throughout the world. Fruits are used in the diet of the population, both fresh and for the production of various processed products, and most importantly, the most popular is dried fruits. In this regard, the topic is relevant both for the agricultural economy and for the country's economy as a whole. Intensive gardening is a combination of technologies, means, resources based on modern, intensive, innovative bases. The purpose of researching the material of the article is to analyze the corresponding situation of intensive gardens in the Republic of Uzbekistan, analyze the development and formulate proposals for increasing the economic attractiveness of cultivating intensive gardens, both for local consumption within the country and for export to foreign countries. The object of the study was the gardening of the Republic of Uzbekistan, in particular, they were accepted for analysis in 2016-2020. The objectives of the study of the material were the study of the economic side of the cultivation of intensive gardens, diagnostics of the state of intensive gardens, based on the analysis, the creation of proposals admissible for adoption on the territory of the Republic of Uzbekistan.
\end{abstract}

\section{Introduction}

Gardening is an important part of agriculture worldwide. Fruits, fruits, berries are irreplaceable products in the human diet, they have a lot of useful medicinal properties. The demand of the population for the fruits of orchards is enormous, in addition to this, Uzbekistan has an export potential for sending agricultural products. In order to provide the population with fresh fruits, processed, and for export, the Republic of Uzbekistan must increase the production of fruits and berries several times [1].

The main direction of the development of the agrarian sector of the Republic of Uzbekistan and other countries of the world is the cultivation of intensive gardens. The

*Corresponding author: sb.i.1@mail.ru 
cultivation of intensive orchards is part of the innovative technology. The roots of the development of intensive gardens go back to 1964 in the city of Canada, where the first experience of growing intensive gardens was carried out.

On the irrigated lands of Uzbekistan, intensive orchards occupy a total of over 15 thousand hectares. Intensive orchards are very effective, all the advantages of this cultivation method can be found in large apple orchards, where different varieties can be grown and harvested even in unfavorable conditions, while apple trees bear fruit only once every 2-3 years. The growing conditions for large varieties of apples are not difficult, but they are difficult to care for. For Industrial enterprises, the cultivation of traditional orchards and semi-intensive orchards with later dates of the onset of fruiting, slow rates of harvest ripening, low productivity, high labor intensity, do not have economic attractiveness [2].

\section{Methods}

In investigating the topic of intensive gardens, various methods are used, in particular the comparative analysis method used when comparing the two types of cultivation of traditional and intensive gardens. Abstract thinking method, looking at intensive gardens from an economic point of view. The method of economic calculation used to calculate the economic feasibility or its absence in the cultivation of intensive gardens in the territory of the Republic of Uzbekistan. The method of expert assessment is applicable when making conclusions and proposals based on the experience of foreign countries [3].

\section{Result}

When cultivating an ordinary orchard, the average yield per hectare is 10-20 tons of apples, with an intensive orchard - at least 20 tons. Experts strive to increase the yield and bring it to 40-50 tons per hectare. The difference between conventional gardens and intensive gardens is in planting technology. "Dwarf" and "Semi-dwarf" trees are planted closely to each other, at a distance of 2 to 3.5 meters, and ordinary tall trees are planted on average at a distance of 4-5 meters from each other [4].

Table 1. Differences between "dwarf" and tall trees.

\begin{tabular}{|c|c|c|c|}
\hline № & Difference & Tall trees & Dwarf trees \\
\hline 1 & Landing distance & $4-5$ Meters & $2-3.5$ Meters \\
\hline 2 & Year of fruiting & In the eighth year & For the first year \\
\hline 3 & Harvest continuity & Unstable & annually \\
\hline 4 & Processing, pruning and so on & A little expensive. & Economical and easy \\
\hline 5 & Age of cultivation of gardens & Under 60 years & 18 years \\
\hline
\end{tabular}

The root system of intensive gardens is located at a depth of half a meter, where there is a high concentration of salt. Thanks to scientists, high soil salinity is no longer a problem. It became possible to plant intensive gardens in such areas as Karakalpakstan, Khorezm, Syrdarya.

The last cultivated variety of intensive tree types is a tree species with a crown of "dwarfs" or "semi-dwarfs" and a root system of tall trees. When cultivating this kind of trees, the productivity has not changed, and the roots at a depth of 2 meters do not absorb moisture from the salty soil layer. The Tashkent and Fergana regions were chosen for 
experimental planting, since this species is intended for all foothill and mountain regions, and in an area with a high degree of salinity [5].

Many farmers cannot adapt to innovative approaches and prefer the traditional type of gardening. Many people do not like the age of intensive gardens - a maximum of 18 years, and for tall ones - up to 60 years.

In the Republic of Uzbekistan in 2016, the average yield of intensive gardens was 168 c/ha, in 2018 - $170 \mathrm{c} / \mathrm{ha}$, and in $2020-176 \mathrm{c} / \mathrm{ha}$. The highest yield was observed in 2020 in the Samarkand region - $201 \mathrm{c} / \mathrm{ha}$, the lowest yield was observed in the Republic of Karakalpakstan - $127 \mathrm{c} /$ ha. The volume of crops grown in intensive gardens in the Republic of Uzbekistan has increased over the years by $12.3 \%$ over the past five years.

Table 2. Dynamics of the yield of existing intensive orchards and the gross harvest in the Republic of Uzbekistan from 2016 -2020 [6].

\begin{tabular}{|l|c|c|c|c|c|c|}
\hline \multirow{2}{*}{\begin{tabular}{l} 
Name of regions \\
\cline { 2 - 7 }
\end{tabular}} & \multicolumn{3}{|c|}{$\begin{array}{c}\text { Gross yield of intensive } \\
\text { orchards, thousand ton }\end{array}$} & \multicolumn{2}{c|}{$\begin{array}{c}\text { Average yield of intensive } \\
\text { orchards, c / ha }\end{array}$} \\
\cline { 2 - 7 } & $\mathbf{2 0 1 6}$ & $\mathbf{2 0 1 8}$ & $\mathbf{2 0 2 0}$ & $\mathbf{2 0 1 6}$ & $\mathbf{2 0 1 8}$ & $\mathbf{2 0 2 0}$ \\
\hline $\begin{array}{l}\text { Karakalpakstan } \\
\text { Republic }\end{array}$ & 2.1 & 121 & 121 & 121 & 2.2 & 2.4 \\
\hline Andijon & 39.4 & 161 & 161 & 161 & 41.1 & 44.4 \\
\hline Bukhara & 22.4 & 149 & 149 & 149 & 23.4 & 25.2 \\
\hline Jizzak & 42.5 & 172 & 172 & 172 & 44.3 & 47.7 \\
\hline Kashkadarya & 15.1 & 133 & 133 & 133 & 15.8 & 17.0 \\
\hline Navoi & 9.4 & 142 & 142 & 142 & 9.9 & 10.6 \\
\hline Namangan & 17.3 & 151 & 151 & 151 & 18.0 & 19.5 \\
\hline Samarkand & 158.0 & 191 & 191 & 191 & 165.4 & 178.0 \\
\hline Surkhandaria & 18.4 & 159 & 159 & 159 & 19.16 & 20.7 \\
\hline Syrdarya & 4.4 & 140 & 140 & 140 & 4.63 & 4.98 \\
\hline Tashkent & 140.6 & 165 & 165 & 165 & 146.7 & 158.0 \\
\hline Fergana & 5.6 & 166 & 166 & 166 & 5.86 & 6.32 \\
\hline Khorezm & 12.4 & 126 & 126 & 126 & 13.0 & 14.0 \\
\hline $\begin{array}{l}\text { In the Republic of } \\
\text { Uzbekistan }\end{array}$ & $\mathbf{4 8 9 . 2}$ & $\mathbf{1 6 8}$ & $\mathbf{1 6 8}$ & $\mathbf{1 6 8}$ & $\mathbf{5 1 0 . 3}$ & $\mathbf{5 4 9 . 5}$ \\
\hline
\end{tabular}

In the economy, the indicator for assessing its effectiveness in terms of per capita indicator according to natural norms is of no small importance. Over the past four years, from 2016 to 2020, per capita horticultural production has grown by an average of $9 \%$. This indicator suggests that there is enough fruit in the country, and they can be exported and made a profit. This is the motivation and goal of developing intensive horticulture and improving the quality and quantity of fruitful production. 


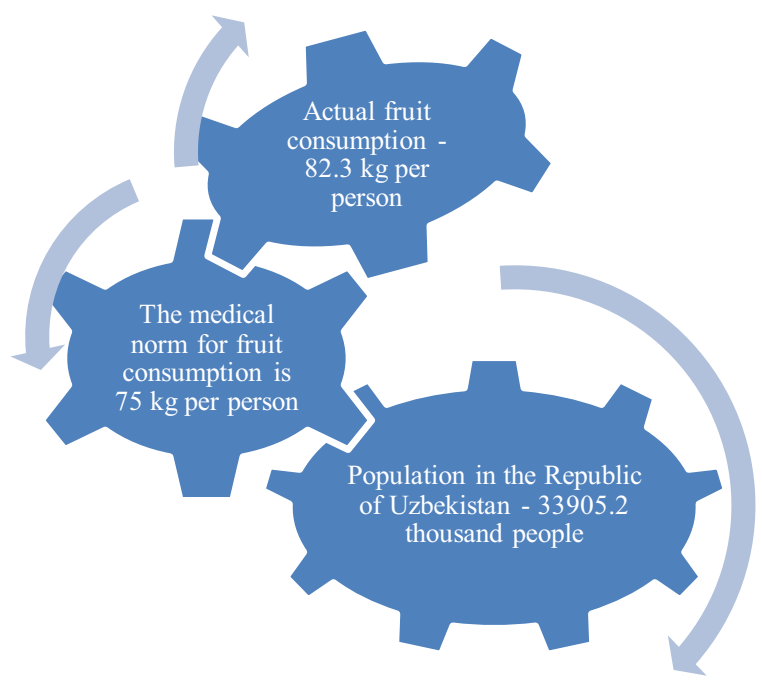

Fig. 1. The volume of fruit and vegetable production per capita in the Republic of Uzbekistan for 2020.

\section{Discussion}

An intensive garden can be viewed as a business as usual, which is made up of many factors. As a mechanism of operation, in the absence of one of the many factors, economic efficiency will be significantly reduced.

The first element in this endeavor is the seedlings. More than $80 \%$ of commercial success comes from seedlings. Seedlings of healthy two-year-old seedlings with an annual crown "knip-baum" - "flowering branch" are used optimally. Today there are more than 20 thousand varieties of apple trees. Intensive varieties are distinguished by their high marketability, fruitfulness, the ability to form intensive flower buds on annual shoots.

If you follow all the techniques and use high-quality planting material, you can get a harvest one year after planting, and the money invested is quickly returned. The "knip" seedling is born in a greenhouse, and from the first year after planting it already bears fruit, which speaks of its ease of breeding. Such a tree bears fruit annually. And it spreads as quickly as possible among the market, and brings good profit. The cost of such a seedling is 2.5 times higher than the cost of ordinary annual seedlings, but the seedling pays for itself faster. An important component is also the selection of supports for seedlings. In intensive orchards, reliable supports are used to support crop-laden trees. Usually, the supports consist of three types of stake supports near each tree, impregnated with creosote or copper sulfate, and 2 types of trellis - from 1-2 rows of wire and a bamboo support near each tree, or from 3-4 rows of wire to which the trees are tied [7, 8].

For an intensive orchard, a drip irrigation system is used - it is expensive, but another irrigation system is less expensive, and will not work in the case of an intensive garden. Permanent adjustments are made to the fertilization system every year, taking into account the content of nutrients in the soil, the activity of vegetative growth, productivity, rainfall, temperature, and other conditions [9].

Another component of the development of an intensive orchard is a pest and disease control system. These include tractors, sprayers, chemicals. It is advisable to use imported sprayers. So, working with a consumption of working fluid of about 260 liters per hectare, 
it reduces the consumption rate of the drug by $25 \%$, and in 4 years the additional costs for the purchase of an imported sprayer are repaid. There are also costs for fencing and antihail installations.

As with other areas of horticulture, infrastructure is essential. The warehouse is an important element to maximize the income from the garden. "Knip" allows you to get $50 \mathrm{t} /$ ha in the second and third years, this is a large amount of harvest and requires certain storage conditions. Renting a refrigerator is a very expensive component, it is cheaper to build your own storage. Many entrepreneurs, before laying a garden, install their own modern refrigerators from two to 5 pieces, which are designed for 5 thousand tons each [10, $11]$.

In terms of manpower, intensive gardens require a minimum of manpower. Modern technologies imply the automation of many processes, even the pruning of trees in an intensive garden. For 10 hectares of intensive orchard, 1 fruit grower manager, 1 machine operator and 2 permanent laborers are needed.

All of these elements combine to make a profit. Let's calculate the cost of setting up an intensive garden with an area of 5 hectares, with 2500 pieces. trees per 1 hectare.

Table 3. The cost of setting up an intensive orchard of 5 hectares, per 1 hectare - 2500 trees.

\begin{tabular}{|c|c|c|c|c|}
\hline № & Type of expense & Quantity & $\begin{array}{c}\text { Price in } \\
\text { dollars }\end{array}$ & $\begin{array}{c}\text { Amount in } \\
\text { dollars }\end{array}$ \\
\hline 1 & Seedlings “knip-baum” & 12500 & 3 & 37500 \\
\hline 2 & $\begin{array}{c}\text { Tree support (One-wire trellis } \\
\text { with bamboo) }\end{array}$ & 12500 & 1.3 & 16615 \\
\hline 3 & Drip irrigation & - & - & 10000 \\
\hline 4 & $\begin{array}{c}\text { Fencing (mesh and reinforced } \\
\text { concrete pillars, every 4 m) }\end{array}$ & - & - & 1450 \\
\hline 5 & $\begin{array}{c}\text { Tractor, sprayer, inter-row } \\
\text { rotary mower, herbicide } \\
\text { sprayer, transport trolley }\end{array}$ & - & - & 9300 \\
\hline \multicolumn{2}{|c|}{ Total } & 74865 \\
\hline
\end{tabular}

Manpower for planting trees, installing supports, installing a drip irrigation system and installing a fence - $\$ 2,000$. Operating annual costs (chemical protection from pests, diseases, fertilization, irrigation, fuels and lubricants, salaries of hired personnel, and so on) - $\$ 22,470$. Overhead costs account for $40 \%$ of the annual costs. The total cost for 15 years of planting per tree is $\$ 30$. One tree provides about $\$ 90$ in net profit. In the third year of harvest, the garden will begin to pay off, after the annual profit from the tree will be above $\$ 100$. One dollar invested in an intensive apple orchard accounts for 2.7 dollars of net profit, excluding tax and other force majeure circumstances [12-14]. This example of calculation allows you to see the profitable side - intensive horticulture.

\section{Conclusions}

The sources of financing for intensive gardens at the moment are the funds of the manufacturing sector and the service sector, directly interested in the development of organizations and various forms of ownership of the storage system, state concessional loans, commercial banks and other financial institutions, leasing companies and funding from sponsors (in the form of various grants) [15].

In the Republic of Uzbekistan, the experience of foreign countries should be applied, of which certain aspects should be highlighted: 
- placement of intensive orchards with associated infrastructure, the state of development of transport logistics, storage facilities

-creation of conditions for the cultivation of organic products in order to export them, both fresh and canned, to European markets

- attracting local private investments and investments of the population in the development of horticulture

- attracting foreign experts with experience in the development of intensive gardens, and versed in foreign markets

- creation of preferential credit lines for organic gardening, as well as the creation of additional conditions from the state in the form of various benefits

- cultivation of non-standard types of fruits in intensive orchards, which are often supplied from foreign countries

\section{Reference}

1. M. Eshov, L. Amirov, M. Askarova, E3S Web Conf. 244, 03014 (2021), DOI: $10.1051 / \mathrm{e} 3$ sconf $/ 202124403014$

2. Resolution of the President of the Republic of Uzbekistan dated December 23, 2015 No. III1-2460 "On measures for further reform and development of agriculture for the period 2016 - 2020" (2015)

3. F.A. Volkov, Method of Research in Horticulture (M.: ISTSP, 2005)

4. A.A. Terpigorev, A.V. Grushin, S.A. Grzybovskiy, Nature-building 1, 36-39 (2009)

5. N.G. Krasova, A.M. Galasheva, Modern gardening 2(2), 26-30 (2010)

6. A.M. Galasheva, N.G. Krasova, Features of the growth and fruiting of apple varieties on semi-dwarf interstitial rootstocks, Improvement of the assortment and technologies of cultivation of fruit and berry crops (materials of the international scientificpractical conference 27.30 July 2010), Eagle. p.46-49 (2010)

7. N.G. Krasova, A.M. Galasheva, Apple varieties in an intensive type garden, Modern approaches to the creation of intensive plantings. Actual problems (materials of the international scientific-practical conference, Khvalynsk, February 25-27, 2014), Saratov: SSAU im. N.I. Vavilov, p. 54-58 (2014)

8. A.D. Sviridova, A.I. Vlasov, Economy and ecology of territorial entities 3, 2, 95-108 (2019)

9. N.A. Chupeeva, Intensive technologies in horticulture (Per. from Polish M.: Agropromizdat, 1990)

10. A. Sadovski, T. Zhultovzhki, R. Dzyuban, Fruit production Samokhvalovichi 19, 229237 (2007)

11. V.A. Gudkovsky, Gardening and viticulture 1, 2-6 (1998)

12. E.A. Egorov, Organizational and economic problems of the development of a regional fruit subcomplex (Krasnodar, 1998)

13. V.I. Kashin, A.C. Kasyanin, Horticulture and viticulture 5-6, 1 (1998)

14. A.S. Kosyakin, et al, Methodological recommendations for determining the economic efficiency of scientific achievements in horticulture (M., 2005)

15. I.A. Minakov, Horticulture and Viticulture 1, 4 (2001) 